\title{
PENGARUH VASEKTOMI TERHADAP FUNGSI SEKSUAL PRIA
}

\author{
${ }^{1}$ Mir'atul Fitri \\ ${ }^{2}$ Benny Wantouw \\ ${ }^{2}$ Lydia Tendean \\ ${ }^{1}$ Kandidat Skripsi Fakultas Kedokteran Universitas Sam Ramtulangi \\ ${ }^{2}$ Bagian Biologi Universitas Sam Ratulangi \\ Email: adinda_afnine@yahoo.co.id
}

\begin{abstract}
Vasectomy in the community are still poorly understood, such as vasectomy can affect sexual function (sexual dysfunction). The purpose of this study was to determine the effect of vasectomy on male sexual function and the mechanisms of sexual function in men due to vasectomy. This study is a cross sectional analytic survey with a target population of men who have vasectomy totaling 67 people selected by proportional sampling of Manado City BKKBN January to August 2012. Instruments in this study using the questionnaire International Index Erectile Function (IIEF), the analysis of the data in this study using univariate analysis and Mann Whitney Sub Menu 2 Independent simple (SPSS 20 for Windows). The results, the majority of respondents aged $>35$ years were 63 people $(94.03 \%)$, elementary education as many as 48 people (62.34\%), earning Rp. 500,000 - Rp. 1.000 .000 by 47 people $(70.1 \%)$, having more than one child as many as 64 people (95.5\%), vasectomy contraceptive users with better sexual function by 56 people (83.60\%), significant results statistics between vasectomy contraceptive users who have comorbidities, consuming drugs and having stress with sexual function. Contraception has no effect on male sexual function and sexual dysfunction occurs due to men having comorbidities, smoking and excessive alkohol consuming in the long term, drug users, and have excessive stress.
\end{abstract}

Keywords: Vasectomy, Sexual Function, Male.

\begin{abstract}
ABSTRAK: Vasektomi dikalangan masyarakat masih kurang dipahami, seperti vasektomi dapat berdampak terhadap fungsi seksual (disfungsi seksual). Tujuan penelitian ini untuk mengetahui pengaruh vasektomi terhadap fungsi seksual pria dan mekanisme fungsi seksual pada pria akibat vasektomi. Penelitian ini bersifat survei analitik pendekatan cross sectional dengan populasi target pria yang telah divasektomi berjumlah 67 orang dipilih secara proporsional sampling dari data BKKBN Kota Manado Januari-Agustus 2012. Instrumen dalam penelitian ini menggunakan Kuesioner Indeks Fungsi Ereksi Internasional (IIEF), analisa data dalam penelitian ini menggunakan analisa univariat dan analisa Mann Whitney Sub Menu 2 Independent simple (SPSS 20 for Windows). Hasil penelitian didapatkan mayoritas responden usia $>35$ tahun sebanyak 63 orang (94,03\%), berpendidikan SD sebanyak 48 orang $(62,34 \%)$, berpenghasilan Rp. 500.000 - Rp. 1.000 .000 sebanyak 47 orang (70,1\%), memiliki anak lebih dari satu orang sebanyak 64 orang $(95,5 \%)$, pengguna kontrasepsi vasektomi dengan fungsi seksual baik sebanyak 56 orang (83,60\%), hasil yang bermakna secara statistik antara pengguna kontrasepsi vasektomi yang memiliki penyakit penyerta, mengkonsumsi narkoba dan mengalami stres dengan fungsi seksual. Kontrasepsi vasektomi tidak berpengaruh pada fungsi seksual pria dan disfungsi seksual terjadi diakibatkan oleh pria memiliki penyakit penyerta, merokok dan mengkonsumsi alhokol dalam jangka waktu panjang dan volume berlebihan, pengguna narkoba, dan memiliki stress berlebihan.
\end{abstract}

Kata kunci: Vasektomi, Fungsi seksual, Pria. 
Dalam rangka upaya pengendalian jumlah penduduk, maka pemerintah menerapkan program Keluarga Berencana (KB). Program KB dan kesehatan reproduksi saat ini tidak hanya ditujukan untuk penurunan angka kelahiran, namun dikaitkan pula dengan tujuan untuk: pemenuhan hak-hak reproduksi, promosi, pencegahan dan penanganan masalah-masalah kesehatan reproduksi dan seksual, serta kesehatan dan kesejahteraan ibu, bayi, dan anak. Salah satu program KB adalah vasektomi. ${ }^{1,2}$

Vasektomi adalah kontrasepsi operatif minor pada pria dengan mengeksisi bilateral vas deferens. Prosedur vasektomi ini sangat aman, sederhana dan efektif. Dimana memakan waktu operasi yang singkat dan hanya menggunakan anastesi lokal. ${ }^{3,4,5}$ Pada dasarnya spermatozoa yang dihasilkan di testis akan dikosongkan ke dalam epididimis melanjutkan melalui duktus (vas) deferens yang berjalan ke cranialis sepanjang dinding posterior testis. Kemudian dari skrotum menuju ke dalam cavitas pelvikum melalui suatu terowongan sempit, canalis linguinalis. Duktus vas deferens adalah pipa penghubung yang mengalirkan sel benih sperma yang diproduksi dari testis menuju kelenjar prostat (diluar kantong zakar). Didalam prostat, sel benih lalu direndam oleh media yang dihasilkan prostat ; cairan seminal dan getah prostat. Dimana komposisi dari cairan seminal dan getah prostat (95\%) dan sel benih / spermatozoa (5\%). Rata-rata ejakulasi mengeluarkan 5 cc air mani, yang mengandung sel benih hanya sekitar 0,15 cc saja. Dan ketiga campuran ini yang disebut sperma. ${ }^{6}$ Pada sterilisasi pria untuk kepentingan keluarga berencana (KB), duktus deferens diikat lalu dipotong untuk mencegah spermatozoa keluar dari testis dan epididimis menuju duktus ejakulatoris dan kemudian uretra. ${ }^{7}$

Fungsi seksual pria adalah kemampuan untuk mengalami keinginan seksual, ereksi, orgasme, ejakulasi dan pemulihan fase siklus respons seksual. ${ }^{8}$

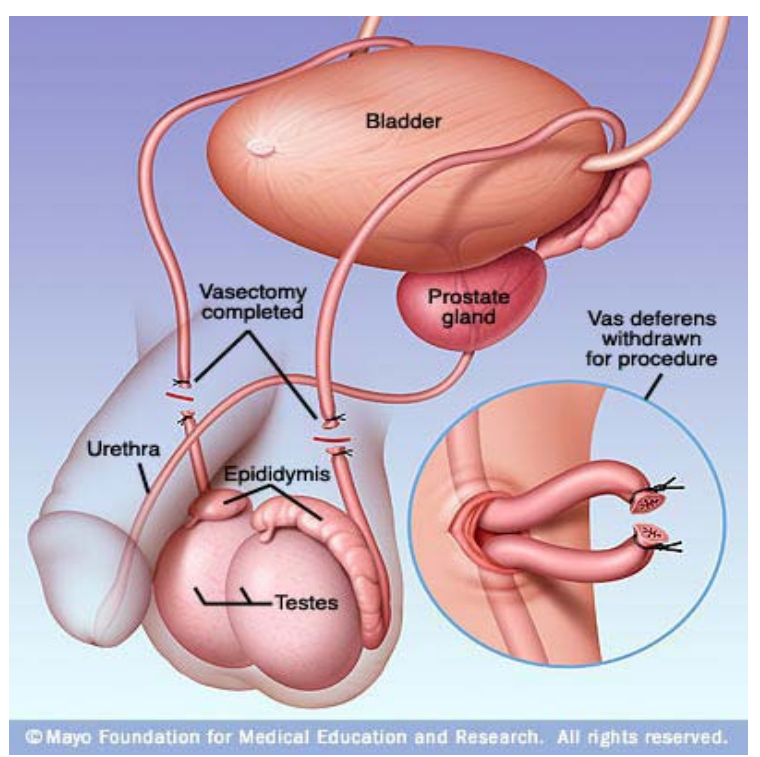

Gambar 1. Vasektomi ${ }^{13}$

Akan tetapi masih banyak warga masyarakat salah memahami vasektomi. Seperti vasektomi dapat berdampak terhadap fungsi seksual (disfungsi seksual). Hal itu menyebabkan rendahnya pemanfaatan vasektomi sebagai alat kontrasepsi pria. Walaupun, metode ini sangat efektif dan aman untuk mencegah kehamilan. Rumor dan fakta tentang vasektomi dimasyarakat seperti tindakan operasi yang menyeramkan, vasektomi sama dengan infertil (mandul), dapat membuat pria impotensi, dapat menurunkan gairah seks (libido), membuat pria tidak bisa ejakulasi, pria / suami dapat dengan mudah untuk selingkuh dan bebarapa pria cemas terhadap prosedur pelaksanaan vasektomi. Selain itu, ada anggapan keliru bahwa pria yang sudah divasektomi akan kehilangan gairah seksual. Padahal yang berbeda setelah vasektomi hanya sperma tidak keluar saat ejakulasi, dengan demikian tidak terjadi kehamilan. Jika saluran yang dipotong ingin disambung lagi, hal itu dimungkinkan. Kurangnya sosialisasi menyebabkan pemahaman tentang vasektomi keliru sehingga pria yang melakukan vasektomi pun rendah., ${ }^{2,9}$ Fungsi seksual pria adalah kemampuan untuk mengalami keinginan seksual, ereksi, orgasme, ejakulasi dan pemulihan fase siklus respons seksual. ${ }^{10}$ 
Akan tetapi dari beberapa penelitian melaporkan bahwa adanya peningkatan dalam fungsi seksual, terutama dalam domain dari keinginan dan kepuasan seksual pada kelompok pasien yang menjalani vasektomi dan tidak ada kasus terkait dengan disfungsi ereksi. ${ }^{11}$ Adapun penelitian yang membandingkan fungsi seksual antara kelompok yang telah divasektomi dan tidak divasektomi, dengan hasil yang menunjukkan bahwa fungsi seksual pada kelompok yang telah divasektomi tidak lebih umum daripada kelompok yang tidak divasektomi Dan juga dikatakan pada hasil penelitian bahwa pria yang telah melakukan vasektomi tidak memiliki masalah seksual yang spesifik. $^{12}$

Berdasarkan uraian di atas, maka penulis tertarik untuk melakukan penelitian dengan topik pengaruh vasektomi terhadap fungsi seksual. Tujuan penelitian ini untuk mengetahui pengaruh vasektomi terhadap fungsi seksual pria dan mengetahui mekanisme fungsi seksual pada pria akibat vasektomi.

\section{METODE PENELITIAN}

Penelitian ini adalah suatu penelitian bersifat survei analitik dengan pendekatan cross sectional. Tempat penelitian dilaksanakan di Kecamatan Arakan Kabupaten Minahasa Selatan yang telah dilaksanakan pada bulan November 2012 - Januari 2013. Populasi target perwakilan pria yang telah divasektomi berjumlah 67 orang dari 199 yang terdaftar di BKKBN kota Manado pada periode Januari - Agustus 2012 yang dipilih secara proporsional sampling. Kriteria inklusi pada penelitian ini ialah pria yang telah melakukan kontrasepsi mantap vasektomi, berusia diatas 30 tahun dan dibawah 70 tahun, telah menikah dan memiliki istri, dan bersedia menjadi subjek penelitian. Kriteria ekslusi ialah pria yang tidak memiliki anak. Variabel penelitian ini ialah usia adalah rentang kehidupan yang diukur dengan tahun, pendidikan responden adalah pendidikan formal pendidikan responden terdiri atas SD, SMP, SMA dan Perguruan Tinggi, penghasilan adalah setiap tambahan kemampuan ekonomis yang diterima atau diperoleh dari usaha yang dapat dipakai untuk konsumsi atau untuk menambah kekayaan, jumlah anak adalah jumlah anak yang masih hidup yang dimiliki seseorang, fungsi seksual pria adalah suatu yang berkenaan dengan perkara persetubuhan dengan interaksi yang kompleks meliputi pikiran, ingatan, emosi dan tubuh pada pria, dan tingkat stress adalah hasil penilaian terhadap berat ringannya stres (suatu reaksi tubuh yang dipaksa).

Alat yang digunakan untuk pengumpulan data adalah kuesioner tertutup. Kuesioner yang digunakan kuesioner terstandar internasional yaitu IIEF 15 (International Index of Erectile Function.). Metode pengumpulan data yang digunakan dalam penelitian ini yaitu kuesioner dan studi pustaka merupakan data dan mempelajari buku-buku referensi dan literatur sebagai penunjang dan pelengkap dari masalah yang sedang diteliti sebagai pedoman dan landasan teoritis. Analisis data dalam penelitian ini dilakukan bertahap meliputi analisis univariat untuk menghitung distribusi frekuensi dan analisis Mann Whitney Sub Menu 2 Independent simple (SPSS versi 20 for Windows) untuk mendapatkan hasil yang bermakna.

\section{HASIL PENELITIAN}

Berdasarkan penelitian yang dilakukan kepada pria yang telah divasektomi sebanyak 67 orang, telah diolah dan disusun dalam tabel sebagai berikut:

Tabel 1. Distribusi pengguna kontrasepsi vasektomi menurut usia

\begin{tabular}{lcc}
\hline \multirow{2}{*}{ Usia } & \multicolumn{2}{c}{ Responden } \\
& N & \% \\
\hline$\leq 35$ tahun & 4 & 5,97 \\
$>35$ tahun & 63 & 94,03 \\
Total & 67 & 100 \\
\hline
\end{tabular}


Tabel 2. Distribusi pengguna kontrasepsi vasektomi menurut pendidikan

\begin{tabular}{lcc}
\hline \multirow{2}{*}{ Pendidikan } & \multicolumn{2}{c}{ Responden } \\
& N & \% \\
\hline SD & 48 & 62,34 \\
SMP & 15 & 19,48 \\
SMA & 14 & 18,18 \\
Total & 67 & 100 \\
\hline
\end{tabular}

Tabel 3. Distribusi pengguna kontrasepsi vasektomi menurut penghasilan

\begin{tabular}{lcc}
\hline \multirow{2}{*}{ Penghasilan } & \multicolumn{2}{c}{ Responden } \\
& N & \% \\
\hline$<500.000$ & 16 & 23,9 \\
$500.000-$ & 47 & 70,1 \\
1.000 .000 & & \\
$1.000 .000-$ & 4 & 6,0 \\
2.000 .000 & 67 & 100 \\
Total & \\
\hline
\end{tabular}

Tabel 4. Distribusi pengguna kontrasepsi vasektomi menurut jumlah anak

\begin{tabular}{lcc}
\hline \multirow{2}{*}{ Jumlah anak } & \multicolumn{2}{c}{ Responden } \\
& N & \% \\
\hline Memiliki anak 1 & 3 & 4,5 \\
Memiliki anak $>1$ & 64 & 95,5 \\
Total & 67 & 100 \\
\hline
\end{tabular}

Tabel 5. Distribusi pengaruh pengguna kontrasepsi vasektomi dengan fungsi seksual (IIEF 15)

\begin{tabular}{lcc}
\hline \multirow{2}{*}{ Fungsi Seksual } & \multicolumn{2}{c}{ Responden } \\
& N & \% \\
\hline Normal & 56 & 83,6 \\
Disfungsi & 11 & 16,4 \\
Total & 67 & 100,0 \\
\hline
\end{tabular}

Tabel 6. Distribusi pengguna kontrasepsi vasektomi yang memiliki penyakit penyerta dengan fungsi seksual

\begin{tabular}{lccc}
\hline & \multicolumn{2}{c}{ Fungsi seksual } & \multirow{2}{*}{ Total } \\
\cline { 2 - 3 } & Normal & Disfungsi & \\
\hline Penyakit & 0 & 2 & 2 \\
Tidak penyakit & 56 & 9 & 65 \\
Total & 56 & 11 & 67 \\
\hline
\end{tabular}

Tabel 7. Distribusi pengguna kontrasepsi vasektomi yang merokok dengan fungsi seksual

\begin{tabular}{lccc}
\hline & \multicolumn{2}{c}{ Fungsi seksual } & \\
\cline { 2 - 3 } & Normal & $\begin{array}{c}\text { Disfungsi } \\
\text { Seksual }\end{array}$ & Total \\
\hline Merokok & 38 & 8 & 46 \\
Tidak & 18 & 3 & 21 \\
merokok & 56 & 11 & 67 \\
Total & 56 \\
\hline
\end{tabular}

Tabel 8. Distribusi pengguna kontrasepsi vasektomi yang Mmngkonsumsi alkohol dengan fungsi seksual

\begin{tabular}{lccc}
\hline & \multicolumn{2}{c}{ Fungsi seksual } & Total \\
\cline { 2 - 3 } & Normal & $\begin{array}{c}\text { Disfungsi } \\
\text { Seksual }\end{array}$ & \\
\hline Alkohol & 6 & 3 & 9 \\
Tidak & 50 & 8 & 58 \\
Alkohol & 56 & 11 & 67 \\
Total & & & \\
\hline
\end{tabular}

Tabel 9. Distribusi pengguna kontrasepsi vasektomi yang mengkonsumsi narkoba dengan fungsi seksual

\begin{tabular}{lccc}
\hline & \multicolumn{2}{c}{ Fungsi seksual } & Total \\
\cline { 2 - 3 } & Normal & $\begin{array}{c}\text { Disfungsi } \\
\text { Seksual }\end{array}$ & \\
\hline Narkoba & 0 & 2 & 2 \\
Tidak & 56 & 9 & 65 \\
narkoba & 56 & 11 & 67 \\
Total & & & \\
\hline
\end{tabular}

Tabel 10. Distribusi pengguna kontrasepsi vasektomi pada tingkat stress dengan fungsi seksual

\begin{tabular}{lccc}
\hline & \multicolumn{2}{c}{ Fungsi seksual } & Total \\
\cline { 2 - 3 } & Normal & $\begin{array}{c}\text { Disfungsi } \\
\text { Seksual }\end{array}$ & \\
\hline Tidak Stress & 36 & 2 & 38 \\
Stress ringan & 20 & 3 & 23 \\
Stress & 0 & 5 & 5 \\
sedang & 0 & 1 & 1 \\
Stress berat & 56 & 11 & 67 \\
Total & &
\end{tabular}




\section{BAHASAN}

Dari hasil penelitian yang telah dilakukan pada pria yang telah divasektomi sebanyak 67 orang didapatkan distribusi pengguna kontrasepsi vasektomi menurut usia responden terbanyak pada usia $>35$ tahun berjumlah 63 orang (94,03\%). Hasil ini sesuai dengan program pemerintah yang menganjurkan akseptor untuk menggunakan alat kontrasepsi vasektomi pada usia diatas 35 tahun. $^{14}$

Dari Tabel 2 distribusi pengguna kontrasepsi vasektomi menurut tingkat pendidikan menggambarkan bahwa responden yang telah divasektomi didapatkan paling banyak berpendidikan sekolah dasar dengan jumlah responden sebanyak 48 orang (62,34\%). Hasil penelitian ini menunjukkan bahwa mayoritas responden adalah tamat pendidikan dasar. Dan hal ini memungkinkan responden untuk dapat bekerjasama serta mudah menerima penyuluhan yang diberikan oleh tenaga kesehatan. Disebabkan makin tinggi tingkat pendidikan, makin mudah menerima informasi, sehingga makin banyak pula pengetahuan yang dimiliki sebaliknya pendidikan yang kurang akan menghambat perkembangan sikap terhadap nilai-nilai yang baru diperkenalkan. ${ }^{14}$

Pada tabel IV.3 distribusi pengguna kontrasepsi vasektomi menurut penghasilan yang didapatkan responden rata-rata tiap bulan terdata sebanyak 47 orang $(70,1 \%)$ berpenghasilan dalam kisaran Rp. 500.000 Rp. 1.000.000 Alasan ekonomi menerangkan rendahnya pendapatan dapat berpengaruh dalam pemilihan penggunaan kontrasepsi. Tingkat ekonomi seseorang saat ini dapat berpengaruh terhadap kemampuan seseorang dalam memiliki anak. Banyak orang tua yang takut jika banyak anak dapat menimbulkan masalah ekonomi yang baru dalam kehidupan rumah tangga mereka, sehingga mereka memilih salah satu kontrasepsi yang dianggap dapat mencegah kehamilan, diantaranya dengan pemilihan kontrasepsi mantap berupa vasektomi. Mereka menganggap bahwa dengan vasektomi maka tidak akan terjadi lagi kehamilan dan mereka tidak akan memiliki anak lagi. ${ }^{14}$

Pada penelitian ini distribusi pengguna kontrasepsi vasektomi dengan jumlah anak menunjukkan responden yang memiliki anak $>1$ orang sebanyak 64 orang (95,5\%). Dimana hal ini berkaitan indikasi program BKKBN dengan pertimbangan untuk melakukan vasektomi yaitu pasangan suami istri tidak menghendaki kehamilan lagi dikarenakan anak yang sudah banyak. ${ }^{3}$

Tabel 5 distribusi pengaruh pengguna vasektomi dengan fungsi seksual didapatkan dari sejumlah responden yang mengikuti penelitian didapatkan dari 56 responden (83,6\%) memiliki fungsi seksual yang baik, dan sisanya disfungsi seksual. Dari penelitian ini terlihat bahwa vasektomi tidak berpengaruh pada fungsi seksual pria. Pada wawancara langsung dengan salah satu responden mengatakan "mulai dari saya divasektomi sampai dengan sekarang tidak ada perubahan pada fungsi seksual (hasrat seksual, ereksi, ejakulasi dan kepuasan) saya sebelum dan sesudah divasektomi". ${ }^{15}$ Penelitian ini sesuai dengan penelitian yang pernah dilakukan di Australia dimana tidak terdapat perubahan yang spesifik terhadap fungsi seksual pria yang telah divasektomi. ${ }^{12}$

Pada penelitian ini didapatkan dari data yang ada, ada 11 orang dari pengguna kontrasepsi vasektomi mengalami disfungsi seksual. Dimana hal ini dipengaruhi faktor lain seperti pada Tabel $6-10$. Salah satu faktor disfungsi seksual terjadi pada pengguna kontrasepsi vasektomi yang memiliki penyakit penyerta. Pada Tabel 6 distribusi pengguna kontrasepsi vasektomi yang memiliki penyakit penyerta dengan fungsi seksual didapatkan hasil yang bermakna.. Pada penelitian ini didapatkan 2 orang yang mengalami disfungsi seksual memiliki penyakit penyerta yaitu hipertensi. Pada kasus ini terjadinya disfungsi seksual disebabkan karena konsumsi golongan obat beta blockers dan diuretik. Dua golongan obat ini bekerja dengan cara mengurangi dan mempertahankan tekanan darah tetap rendah ketika darah mengalir ke penis. Hal ini dapat mengganggu salah satu bagian dari fungsi seksual yaitu pada proses ereksi. ${ }^{16}$ 
Pada Tabel 7 distribusi pengguna kontrasepsi vasektomi yang merokok dengan fungsi seksual didapatkan hasil yang tidak bermakna. Akan tetapi beberapa sumber yang ada menerangkan bahwa rokok dapat menyebabkan disfungsi seksual. Hal ini terjadi jika merokok menyebabkan terjadinya penyempitan pembuluh darah pada sistem vaskular yang mengarah ke penyumbatan arteri. Penis yang tidak mendapatkan darah yang cukup akan menyebabkan arteri tersumbat dan akibatnya penis tidak bisa ereksi ${ }^{17}$ Dan sumber lain mengatakan bahwa pria yang merokok dalam jangka waktu yang lebih lama lebih rentan menderita impotensi. ${ }^{18}$

Pada Tabel 8 distribusi pengguna kontrasepsi vasektomi yang mengkonsumsi alkohol dengan fungsi seksual didapatkan hasil yang tidak bermakna. Namun beberapa sumber menyatakan konsumsi yang berlebihan secara bertahap akan menyebabkan impotensi. Alkohol mempengaruhi sistem saraf dan mengganggu impuls antara kelenjar hipofisis otak dan alat kelamin. Studi klinis telah menunjukkan bahwa penyalahgunaan alkohol berkepanjangan menyebabkan kerusakan permanen pada saraf di penis, yang menghasilkan impotensi. Minum alkohol berlebihan juga menghasilkan perubahan perilaku yang mengurangi hasrat seksual dan menghambat kinerja seksual. Dimana Alkohol juga mengganggu tingkat hormon, khususnya testosteron dan estrogen. Rendahnya tingkat testosteron mengurangi fungsi hasrat seksual pria. ${ }^{19}$

Pada Tabel 9 distribusi pengguna kontrasepsi vasektomi yang mengkonsumsi narkoba dengan fungsi seksual didapatkan hasil yang bermakna. Hal ini sesuai dengan beberapa sumber menjelaskan keterkaitan pengaruh narkoba terhadap disfungsi seksual pria bahwa pada dasarnya kokain akan sangat mempercepat penuaan arteri, menyebabkan plak dan kalsifikasi dipercepat sehingga mudah mengakibatkan gangguan pada pembuluh darah penis yang dapat menyebabkan disfungsi ereksi. Penggunaan kokain kronis akan mendapatkan salah satu faktor risiko utama untuk penyakit jantung. Adapun tentang heroin yang menghancurkan hampir setiap fungsi gonad dapat menurunkan volume ejakulasi, vesikuler mani dan cairan prostat lebih dari setengah volume dari orang normal. ${ }^{20}$

Pada Tabel 10 distribusi pengguna kontrasepsi vasektomi pada tingkat stress dengan fungsi seksual didapatkan hasil yang bermakna. Adanya stres, kecemasan dan depresi juga bisa menjadi faktor penyebab terjadinya ejakulasi dini pada pria. Hal ini disebabkan karena stres akan terjadi pelepaskan hormon kortisol yang diyakini bisa menjadi penyebab terjadinya ejakulasi dini pada pria. ${ }^{21}$

\section{SIMPULAN}

Dari Penelitian yang telah dilakukan pada 67 pria yang menggunakan vasektomi. Penulis menarik simpulan bahwa kontrasepsi vasektomi tidak berpengaruh pada fungsi seksual pria dan disfungsi seksual pada pria yang divasektomi terjadi diakibatkan oleh: memiliki penyakit penyerta, merokok dan mengkonsumsi alhokol dengan jangka waktu panjang serta dalam volume berlebihan, pengguna narkoba, dan yang memiliki tingkat stress berlebihan.

\section{DAFTAR PUSTAKA}

1. Khotima FN. Hubungan pengetahuan dan sikap istri dengan pemilihan kontrasepsi vasektomi pada pasangan usia subur [Skripsi]. Semarang: UNDIP; 2011.

2. Anonymous. (Diakses pada 23 oktober 2012). Diunduh dari: http://repository.usu.ac.id/bitstream/123 456789/17871/5/Chapter\%20I.pdf.

3. Handayani Sri. Buku ajar pelayanan keluarga berencana.Yogyakarta: Pustaka Rihana, 2010; p.166-82.

4. Albar E. Ilmu Kandungan - Kontrasepsi. Saifudin AB, Rachimhadhi T.Ed.2.jakarta:Pt. Bina Sarwono Praworohardjo, 2008; p.535-75.

5. Gruendemann BJ, Fernsebner B. buku ajar keperawatan perioperatif. Pendit UB. Jakarta: EGC, 2005; p.262.

6. Ammaciang. Definisi tujuan cara dan risiko melakukan vasektomi. 18 januari 2012 (diakses pada 14 Januari 2013). Diunduh dari: http://www.seksualitas.net/ definisi-tujuan-cara-risiko-vasektomi.html. 
7. Tanudjaja GN. Kumpulan Kuliah Anatomi Urogenital. Manado: Bagian Anatomi Fakultas Kedokteran Universitas Sam Ratulangi, 2010; p.3-7.

8. Hartanto H. Keluarga Berencana Dan Kontrasepsi. Jakarta: Sinar Harapan, 2010; p.307-25.

9. Anna LK. Banyak salah paham terkait vasektomi [homepage on the Internet]. Sabtu 2 Juni 2012 [cited 10 Oktober 2012]. Available from: http://health.kompas.com/ read/2012/06/02/08363326/Banyak.Salah.P aham.Terkait.Vasektomi.

10. Kee JL, Hager ER. Farmakologi Pendekatan proses keperawatan. Jakarta: EGC; p.689-92.

11. Bertero E, Hallak J, Gromatzky C, Lucon AM, Arap S. Assessment of sexual function in patients undergoing vasectomy using the international index of erectile function. brazjurol [serial online]. 2005 [cited 2012 Oct 19];31(5):452-8. Available from: http://www.brazjurol.com.br/ september_october_2005/Bertero_ing_452 -458.pdf

12. Smith A, Lyons A, J Ferris, Richters J, M Pitts, dan Shelley J. Apakah masalah seksual lebih sering terjadi pada pria yang memiliki memiliki vasektomi? Sebuah studi berbasis populasi Pria Australia. J Sex Med [serial online]. 2010 [cited 2012 Oct 19];7:736-42. Available from: DOI: 10.1111/j.1743-6109.2009.01565.x.

13. Vasectomy [homepage on the Internet]. Nodate [cited 19 Oktober 2012]. Diunduh dari: http://www.mayoclinic.com/health/ medical/IM03711
14. Rahayu YP. Gambaran karakteristik akseptor vasektomi. 03 Januari 2012 (diakses pada 06 Januari 2013). Diunduh dari: http://duniapintardancemerlang. blogspot.com/2012/01/jurnal-penelitiangambaran.html.

15. Hasan I. Personal communication.

16. Ammaciang. Obat hipertensi sebabkan difungsi ereksi [homepage on the Internet]. 9 September 2011 [cited 07 Januari 2013]. Available from: http://www.seksualitas. net/obat-hipertensisebabkan-disfungsi-ereksi-impotensi.htm\#.

17. Irawan RA. Penyebab impotensi [homepage on the Internet]. 13 April 2012 \{[cited 08 Januari 2013]. Available from: http://jualobatimpotensi.wordpress.com/20 12/04/13/penyebab-impotensi/.

18. Abe B. Merokok sebabkan impotensi November 18, 2011 (diakses 08 Januari 2013). Available from: http://mengatasi ejakulasidinipria.com/merokok-sebabkanimpotensi/

19. Alcohol \& impotence [homepage on the Internet]. Nodate [cited 08 Januari 2013]. Available from: http://www.firstmed.co.uk/ articles/erectile-dysfunction-alcohol.php

20. Disfungsi ereksi - kokain dan heroin [homepage on the Internet]. Nodate [cited 10 Januari 2013]. Available from: http://www.peaktestosterone.com/Cocaine_ Heroin_Erectile_Dysfunction.aspx

21. Vicka. Jauhi hal-hal berikut agar tidak ejakulasi dini [homepage on the Internet]. 18 Juli 2011 [ cited 18 Januari 2013]. Available from: http://id.shvoong.com/ lifestyle/dating/2303748-jauhi-hal-halberikut-agar/\#ixzz2HIulaZyN 